\title{
Corrosion Reason Analysis of 13Cr110 Tubing in an Injection and Production Well of the Suqiao Gas Storage Group
}

\author{
Rui Cai $\mathbb{D}^{1,2}$ Jie Gui, ${ }^{3}$ Mingxing Li, ${ }^{3}$ Binbin Zhao, ${ }^{3}$ Xiaohong Bai, ${ }^{3}$ and Guangxu Cheng $\mathbb{D}^{1}$ \\ ${ }^{1}$ School of Chemical Engineering and Technology, Xi'an Jiaotong University, Xi'an 710049, China \\ ${ }^{2}$ State Key Laboratory for Performance and Structure Safety of Petroleum Tubular Goods and Equipment Materials, CNPC Tubular \\ Goods Research Institute, Xi'an 710077, China \\ ${ }^{3}$ Oil \& Gas Technology Institute of Changqing Oilfield Co. Ltd, Xi'an 710021, China
}

Correspondence should be addressed to Rui Cai; cair@cnpc.com.cn

Received 26 November 2020; Revised 21 February 2021; Accepted 3 March 2021; Published 19 April 2021

Academic Editor: Jiangwei LIU

Copyright (C) 2021 Rui Cai et al. This is an open access article distributed under the Creative Commons Attribution License, which permits unrestricted use, distribution, and reproduction in any medium, provided the original work is properly cited.

\begin{abstract}
Natural gas as a clean energy, its extensive use can alleviate energy crisis and environmental pollution and other problems. The storage and transportation of natural gas are of great significance to the standard use of natural gas. Suqiao gas storage reservoir is responsible for seasonal peak adjustment and emergency gas supply in the Beijing-Tianjin-Hebei region, and the corrosion of tubular goods is the most important issue. In this paper, the tubing composition analysis, metallographic structure analysis, mechanical property analysis, simulated corrosion test, corrosion morphology, and product analysis were carried out to analyze and study the corrosion behavior under the conditions, and suggestions were put forward to control the corrosion of the outer surface of the tubing.
\end{abstract}

\section{Introduction}

According to the 13th Five-Year Plan of Natural Gas, natural gas will account for $10 \%$ of China's disposable energy consumption structure in 2020. The construction of Suqiao gas storage is of great significance to maintaining national energy security and reducing air pollution in the Beijing-TianjinHebei region. The "gas storage" usually refers to underground gas storage. Underground gas storage is a kind of artificial gas field or gas reservoir formed by injecting commodity natural gas from oil and gas fields nearby or long-distance pipeline back into underground space. However, when this method is adopted, corrosion of the tubular goods will inevitably occur [1-6]. If a tube corrodes, it will not only hinder the transportation of natural gas but also may cause an explosion in severe cases [7-13]. Therefore, it is very necessary to study the corrosion behavior of natural gas tubular goods.

An injection-production well in the Suqiao Gas Storage Group was completed on October 15, 2013. The completion tubing was $13 \mathrm{Cr} 110$ with a wall thickness of $6.88 \mathrm{~mm}$ and an outside diameter of $114.3 \mathrm{~mm}$. The schematic diagram of well profile is shown in Figure 1. The well had been in production for 1 year and 6 months, producing 24,521,800 cubic meters of gas. The second operation of the well began on April 30, 2015. A total of 435 gas-sealed tubing were removed from the original well. When the 177th tubing was taken out, rust spots were found on the outer wall of the tubing. After inspection, there were obvious rust blisters on the outer wall of the 200th to 435th tubing, and there were obvious corrosion pits on the surface after removing rust blisters. After the tubing was dissected, it was found that there was no obvious corrosion pit on the internal surface and only different degrees of scaling, which is shown in Figure 2. In order to avoid natural gas leakage and other potential safety hazards, the corrosion causes of tubing were studied.

\section{Materials and Methods}

The samples used in the test were taken from this well, and 4 typical tubing samples were selected from the top, middle, and bottom positions of the wellbore. According to the 


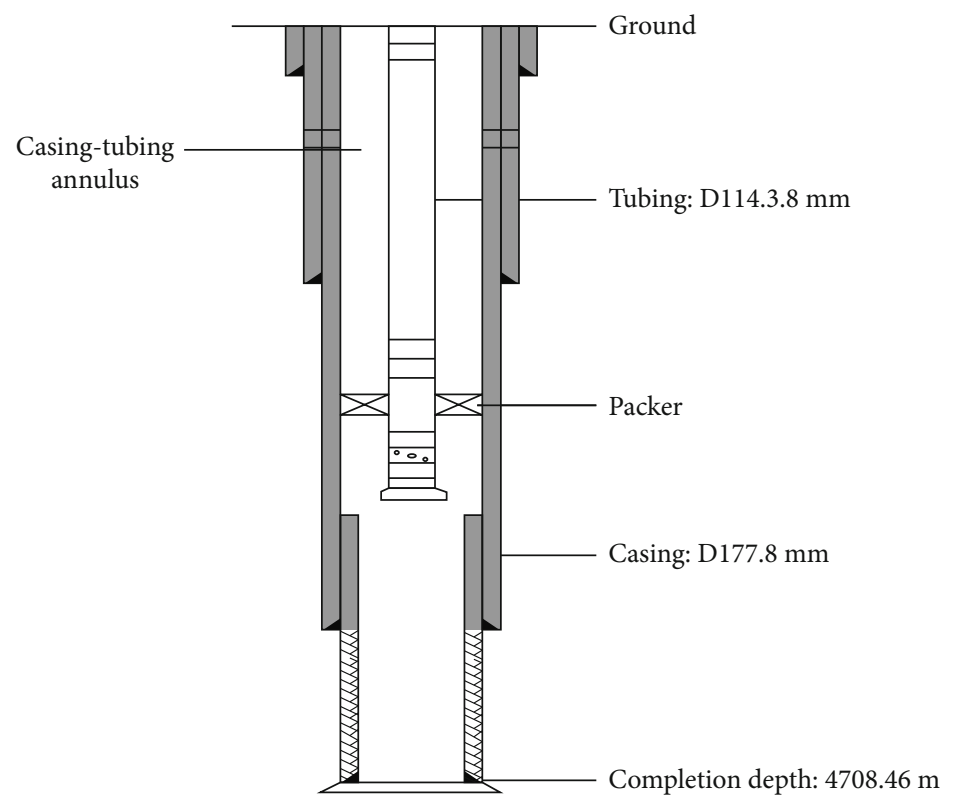

FIgURE 1: Schematic diagram of well profile.

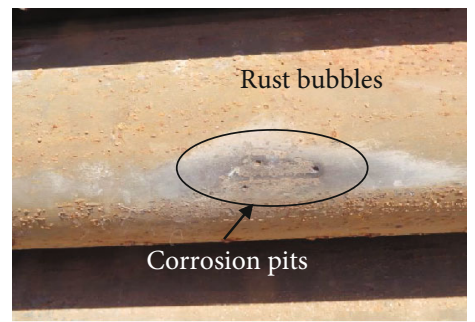

(a)

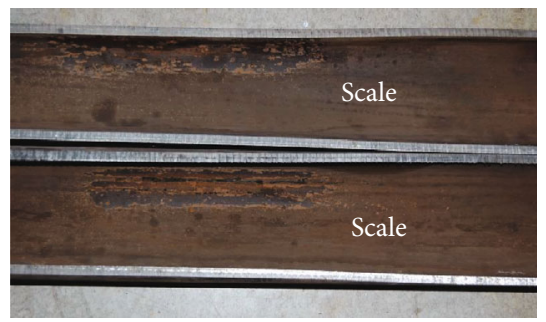

(b)

Figure 2: Macromorphology of tubing corrosion ((a) external surface; (b) internal surface).

extraction sequence, they were the 84th (84\#), the 258th (258\#), the 259th (259\#), and the 364th (364\#), respectively.

The ARL 4460 direct reading spectrometer was used to analyze the chemical compositions of the tubing samples. Metallographic structure, grain size, and inclusions were analyzed by the MeF3A metallographic microscope, MEF4M metallographic microscope, and image analysis system. The tensile properties and Charpy impact properties of the samples were tested, respectively. The high temperature autoclave was used to simulate the working condition on site to evaluate the corrosion resistance of the tubing material. A scanning electron microscope (SEM) was used to analyze the corrosion surface of the tubing. The elements of the corrosion products were analyzed by an energy spectrum analyzer, and the phase of the corrosion products was analyzed by X-ray diffraction.

\section{Results and Discussion}

3.1. Composition Analysis of Tubing Samples. The chemical compositions of four tubing samples were analyzed by the ARL 4460 direct reading spectrometer. The results are shown in Table 1. The results indicated that there was no significant difference in the chemical composition of the four tubing samples, and all of them met the requirements of the API SPEC 5CT standard.

3.2. Metallographic Analysis of Tubing Samples. According to GB/T 13298-2015, ASTM E45-18a, and ASTM E112-13, the metallographic structure, grain size, and nonmetallic inclusion of the 4 tubing samples were tested, and the test results are shown in Table 2 and Figure 3. It can be seen from the analysis results that there was no abnormal metallographic structure of the four tubing samples, all of which were tempered martensite structures, with a grain size of level 9.0 and no extrasized nonmetallic inclusions.

3.3. Testing of Mechanical Properties of Tubing Samples. The Charpy impact and tensile property test of four tubing samples was carried out according to ASTM E23-12C and ASTM A370-14. The results are shown in Tables 3 and 4. The test results showed that the impact and tensile properties of the four tubing met the requirements of API SPEC 5CT.

3.4. Simulated Working Condition Corrosion Test. A $50 \mathrm{~mm}$ $\times 10 \mathrm{~mm} \times 3 \mathrm{~mm}$ hanging piece sample was taken from the four tubing, and a high-temperature autoclave was used for 
TABLE 1: Analysis results of the chemical composition of sample (WT \%).

\begin{tabular}{|c|c|c|c|c|}
\hline $\begin{array}{l}\text { Number } \\
\text { Elements }\end{array}$ & $84 \#$ & $258 \#$ & 259\# & $364 \#$ \\
\hline $\bar{C}$ & 0.027 & 0.023 & 0.024 & 0.025 \\
\hline $\mathrm{Si}$ & 0.14 & 0.18 & 0.15 & 0.17 \\
\hline Mn & 0.41 & 0.38 & 0.39 & 0.38 \\
\hline $\mathrm{P}$ & 0.018 & 0.018 & 0.017 & 0.019 \\
\hline S & 0.0008 & 0.0003 & 0.0007 & 0.0006 \\
\hline $\mathrm{Cr}$ & 12.9 & 12.9 & 13.0 & 13.1 \\
\hline Mo & 0.94 & 0.93 & 0.90 & 0.93 \\
\hline $\mathrm{Ni}$ & 4.4 & 4.4 & 4.4 & 4.4 \\
\hline $\mathrm{Nb}$ & $<0.001$ & $<0.001$ & $<0.001$ & $<0.001$ \\
\hline $\mathrm{V}$ & 0.0050 & 0.0040 & 0.0061 & 0.0045 \\
\hline $\mathrm{Ti}$ & 0.0082 & 0.0069 & 0.0027 & 0.0047 \\
\hline $\mathrm{Cu}$ & 0.026 & 0.030 & 0.033 & 0.030 \\
\hline B & $<0.0001$ & $<0.0001$ & $<0.0001$ & $<0.0001$ \\
\hline $\mathrm{Al}$ & 0.036 & 0.043 & 0.032 & 0.044 \\
\hline
\end{tabular}

TABLE 2: Metallographic analysis results of tubing samples.

\begin{tabular}{|c|c|c|c|c|c|c|c|c|c|c|}
\hline \multirow{3}{*}{ Samples } & \multicolumn{8}{|c|}{ Nonmetallic inclusion } & \multirow{3}{*}{ Metallurgical structure } & \multirow{3}{*}{ Grain size } \\
\hline & \multicolumn{2}{|c|}{ A } & \multicolumn{2}{|c|}{ B } & \multicolumn{2}{|c|}{ C } & \multicolumn{2}{|c|}{$\mathrm{D}$} & & \\
\hline & Thin & Thick & Thin & Thick & Thin & Thick & Thin & Thick & & \\
\hline $84 \#$ & 0.5 & 0 & 0.5 & 0 & 0 & 0 & 0.5 & 0 & Tempered martensite & Level 9.0 \\
\hline $258 \#$ & 0.5 & 0 & 0.5 & 0 & 0 & 0 & 0.5 & 0 & Tempered martensite & Level 9.0 \\
\hline 259\# & 0.5 & 0 & 0.5 & 0 & 0 & 0 & 0.5 & 0 & Tempered martensite & Level 9.0 \\
\hline $364 \#$ & 0.5 & 0 & 0.5 & 0 & 0 & 0 & 0.5 & 0 & Tempered martensite & Level 9.0 \\
\hline
\end{tabular}

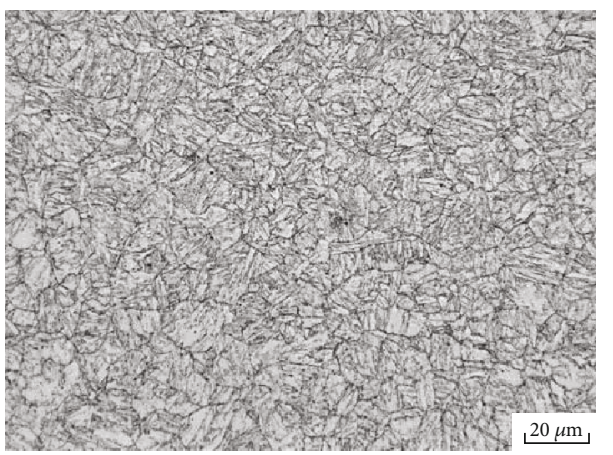

(a)

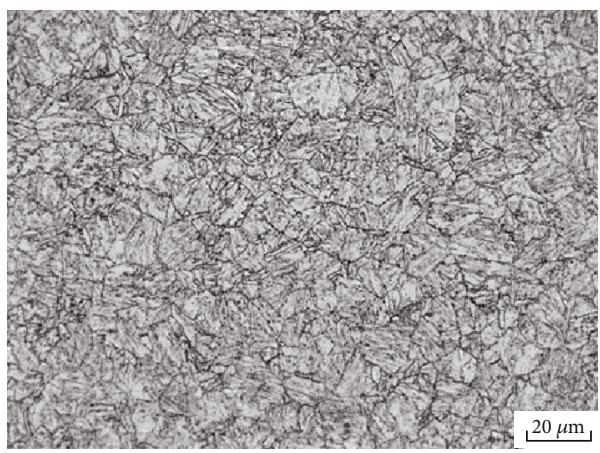

(c)

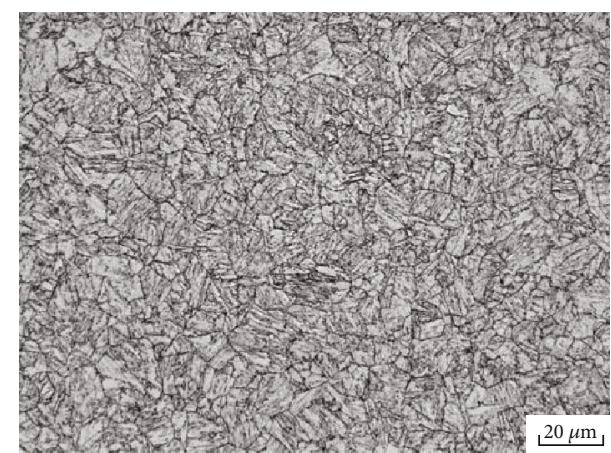

(b)

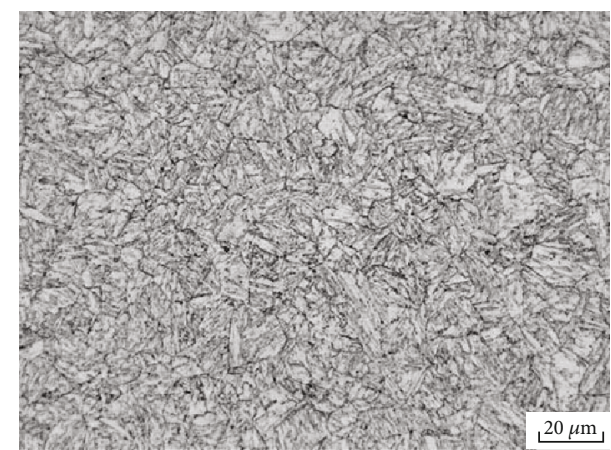

(d)

Figure 3: Metallographic diagrams of tubing samples ((a) 84\#, (b) 258\#, (c) 259\#, and (d) 364\#). 
TABLE 3: Test results of Charpy impact performance of tubing.

\begin{tabular}{|c|c|c|c|c|c|c|c|c|c|}
\hline \multirow{2}{*}{$\frac{\text { Number }}{84 \#}$} & \multirow{2}{*}{$\begin{array}{l}\text { Samples } \\
\text { Size }(\mathrm{mm})\end{array}$} & \multirow{2}{*}{ Notch shape } & \multirow[t]{2}{*}{ Temperature $\left({ }^{\circ} \mathrm{C}\right)$} & \multicolumn{3}{|c|}{ Absorbed energy (J) } & \multicolumn{3}{|c|}{ Shear section rate (\%) } \\
\hline & & & & 116 & 108 & 107 & 100 & 100 & 100 \\
\hline $258 \#$ & \multirow{3}{*}{$5 \times 10 \times 55$} & \multirow{3}{*}{$\mathrm{V}$} & \multirow{3}{*}{0} & 131 & 129 & 128 & 100 & 100 & 100 \\
\hline $259 \#$ & & & & 128 & 134 & 121 & 100 & 100 & 100 \\
\hline $364 \#$ & & & & 131 & 131 & 121 & 100 & 100 & 100 \\
\hline \multicolumn{4}{|c|}{ API SPEC 5CT standard } & \multicolumn{3}{|c|}{$\geq 22.55$} & \multicolumn{3}{|c|}{1} \\
\hline
\end{tabular}

TABLE 4: Test results of tubing tensile properties.

\begin{tabular}{lccc}
\hline \multirow{2}{*}{$\begin{array}{l}\text { Number } \\
\text { Width } \times \text { gauge length }(\mathrm{mm})\end{array}$} & $\begin{array}{c}\text { Strength of extension } \\
R_{m}(\mathrm{MPa})\end{array}$ & $\begin{array}{c}\text { Yield strength } \\
R_{t 0.5}(\mathrm{MPa})\end{array}$ & 866 \\
$A(\%)$
\end{tabular}

TABLE 5: Test conditions.

\begin{tabular}{|c|c|c|c|c|c|c|c|}
\hline Condition & $\begin{array}{c}\text { Temperature } \\
\left({ }^{\circ} \mathrm{C}\right)\end{array}$ & $\begin{array}{c}\text { Content of } \mathrm{CO}_{2} \\
(\% \mathrm{vol})\end{array}$ & $\begin{array}{l}\text { Gas phase } \\
\text { Content of } \mathrm{O}_{2} \\
(\% \mathrm{vol})\end{array}$ & $\begin{array}{c}\text { Total pressure } \\
(\mathrm{MPa})\end{array}$ & Liquid phase & $\begin{array}{l}\text { Test time } \\
\text { (h) }\end{array}$ & Sample location \\
\hline 1 & 90 & 2.5 & 0 & 20 & \multirow{2}{*}{$\begin{array}{l}\text { Shown in } \\
\text { Table } 6\end{array}$} & 168 & $\begin{array}{c}\text { Gas phase, liquid } \\
\text { phase }\end{array}$ \\
\hline 2 & 90 & 2.5 & 0.1 & 20 & & 168 & $\begin{array}{c}\text { Gas phase, liquid } \\
\text { phase }\end{array}$ \\
\hline
\end{tabular}

TABLE 6: Simulated formation water compositions.

\begin{tabular}{lccccccr}
\hline Ion type & $\mathrm{HCO}_{3}{ }^{-}$ & $\mathrm{Cl}^{-}$ & $\mathrm{SO}_{4}{ }^{2-}$ & $\mathrm{Ca}^{2+}$ & $\mathrm{Mg}^{2+}$ & $\mathrm{Na}^{+}+\mathrm{K}^{+}$ & $\mathrm{Water} \mathrm{type}^{-}$ \\
\hline Concentration $(\mathrm{mg} / \mathrm{L})$ & 309.4 & 5240.9 & 162.8 & 634.1 & 123.6 & 2632.1 & $\mathrm{CaCl}_{2}$ \\
\hline
\end{tabular}




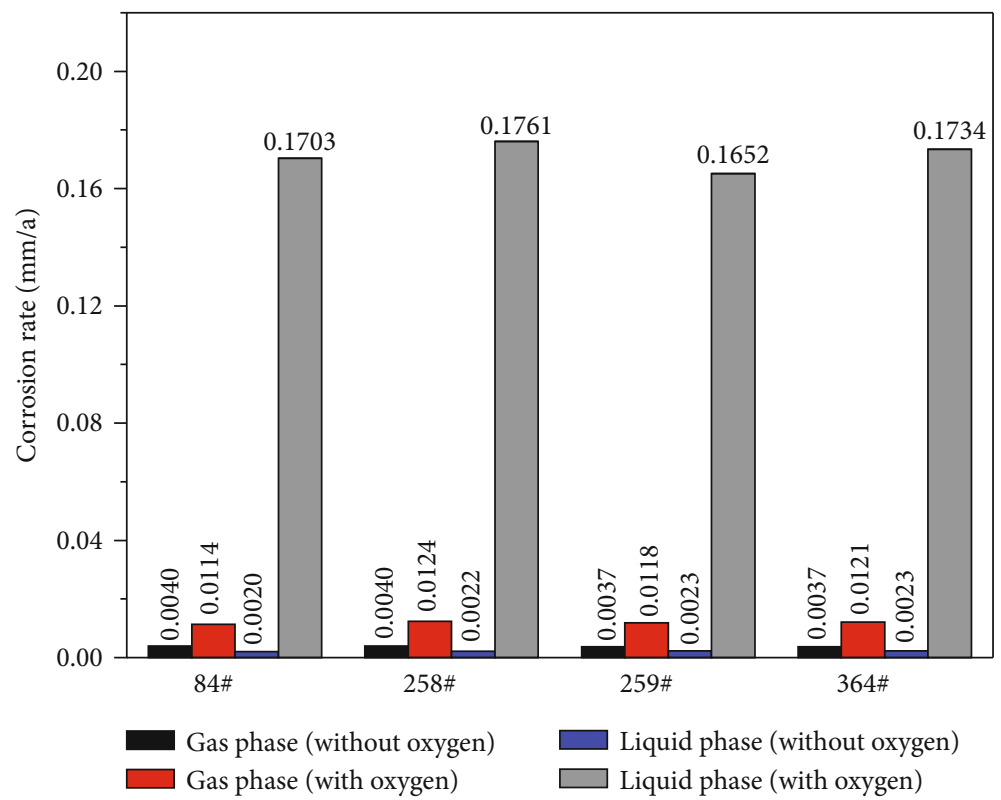

Figure 4: Corrosion rate test results of four tubing samples under different conditions.

the laboratory corrosion test to simulate the on-site working conditions. The test conditions are presented in Table 5, and the compositions of simulated formation water are shown in Table 6.

Figure 4 shows the corrosion rate test results of the four tubing samples under different conditions. It could be seen from the figure that there were no obvious differences for corrosion resistance of the four tubing materials. Compared with the conditions without oxygen, the corrosion rate of the sample in the gas phase increased by $2 \sim 3$ times and in the liquid phase by 70 80 times. In the absence of dissolved oxygen, the corrosion rate of the sample in the liquid phase was about 2 times that in the gas phase. In the case of dissolved oxygen, the corrosion rate of the sample in the liquid phase was much higher than that in the gas phase, which was about 15 times.

Figure 5 shows the morphologies of the sample surface before and after the test. It could be seen from the figure that the corrosion degree of the samples in the gas phase was light, and the original wear marks could still be observed. The samples showed uniform corrosion in the liquid phase without oxygen, and there was no obvious corrosion pit on the surface. There was obvious local corrosion in the liquid phase in the presence of oxygen, and a large number of corrosion pits could be seen on the surface. It could be concluded that dissolved oxygen is the main factor leading to the corrosion of the tubing outer wall.

3.5. Analysis of Corrosion Products. As the corrosion degree of the outer wall of 84\# tubing was relatively light, with only a small amount of floating rust on the surface and no obvious corrosion pits, the research on corrosion products was mainly focused on the corrosion pits of 258\#, 259\#, and 364\# tubing samples. The surface morphology of the corrosion pit was observed by a scanning electron microscope
(SEM), and the element composition of the inside and outside surface of the corrosion pit was analyzed by an energy dispersive spectrometer. Figure 6 shows the surface morphologies of the samples at low magnification. It could be seen from the figure that there was a thin layer on the sample surface, and there were obvious corrosion pits locally. The corrosion pits were round in shape, with a diameter of about $2-3 \mathrm{~mm}$, and were all in the positions where the thin-layer broke or bulged.

Figures 7-9 show the surface morphologies of the corrosion pit and the results of energy spectrum analysis of the corrosion products inside and outside the corrosion pit. Tables 7-9 suggest the analysis results of the components of the corrosion products at different parts of the sample surface. The results illustrated that the corrosion pits were round, with a diameter of about $2 \sim 3 \mathrm{~mm}$. Also, they were all in the position of surface rupture or uplift caused by a thin layer. The content of $\mathrm{Cr}$ and $\mathrm{Ni}$ at the bottom of the corrosion pit was significantly higher than that outside the corrosion pit, while the content of $\mathrm{Fe}$ in the corrosion pit was significantly lower than that outside the corrosion pit. The content of Ca element in the thin layer substance on the surface of the sample was very high, which was much higher than that in the bottom of the corrosion pit and outside the corrosion pit, and the content of $\mathrm{Fe}, \mathrm{Cr}$, and $\mathrm{Ni}$ was much lower than that in the corrosion pit and outside the corrosion pit.

X-ray diffraction was used for phase analysis of the surface corrosion products of the samples. Figure 10 shows the results of sample analysis. The results indicated that the sample surface mainly contained $\mathrm{Fe}_{3} \mathrm{O}_{4}$ and $\mathrm{CaCO}_{3}$. Therefore, it can be concluded that the thin-layered material on the outer surface of the three tubing samples was $\mathrm{CaCO}_{3}$, which was formed by surface scaling. $\mathrm{Fe}_{2} \mathrm{O}_{3}$ and $\mathrm{Fe}_{3} \mathrm{O}_{4}$ were the main corrosion products. 


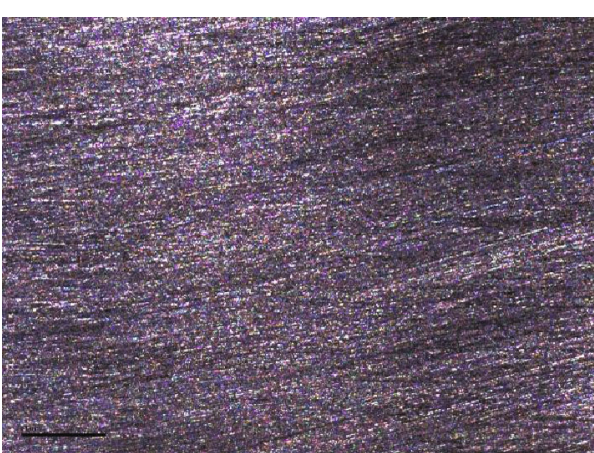

(a)

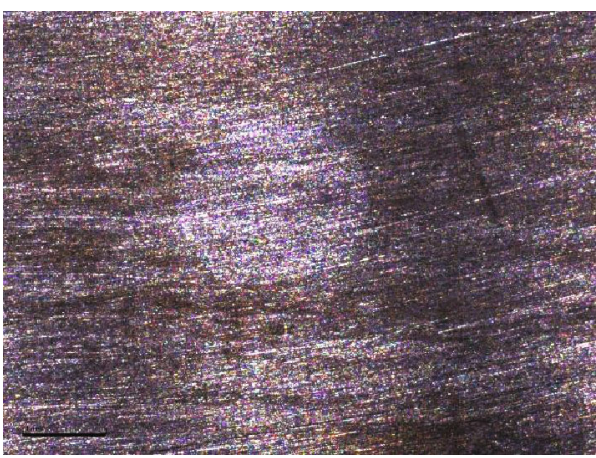

(c)

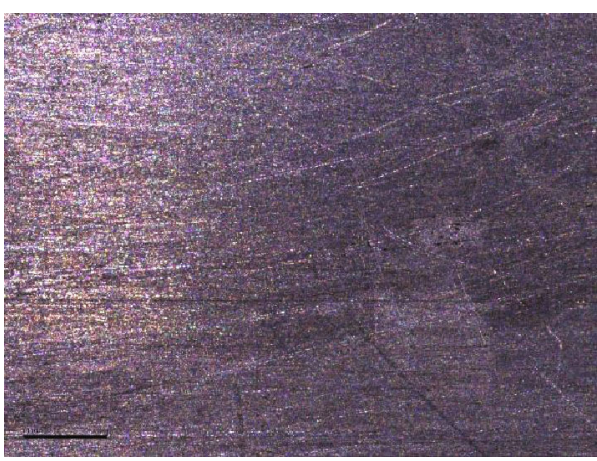

(b)

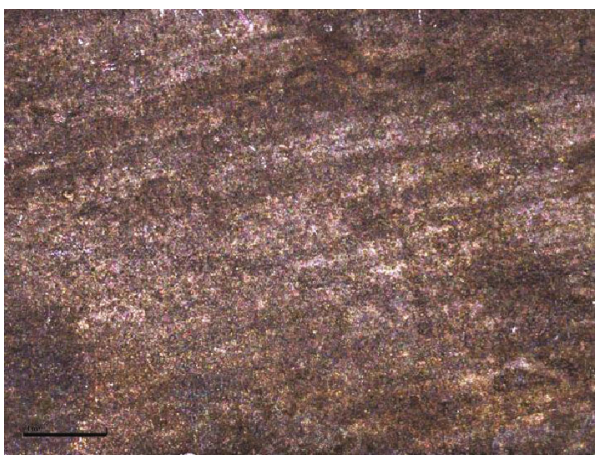

(d)

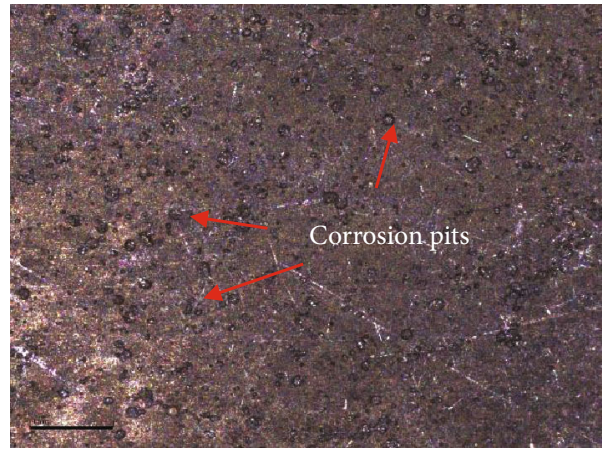

(e)

FIGURE 5: Surface morphologies of samples before and after the test ((a) before test, (b) gas phase without oxygen, (c) gas phase with oxygen, (d) liquid phase without oxygen, and (e) liquid phase with oxygen).

\section{Comprehensive Analysis of Corrosion Reason}

4.1. Corrosion Characteristics. The corrosion mainly occurred on the outer surface of the tubing, and the seriously corroded samples are located in the middle and lower part of the well. There was a thin layer of material on the outer surface of the tubing. There were obvious corrosion pits on the surface. The corrosion pits were in the position where the thin layer of material on the surface breaks or bulges. The surface of the sample mainly contains $\mathrm{Fe}_{2} \mathrm{O}_{3}, \mathrm{Fe}_{3} \mathrm{O}_{4}$, and $\mathrm{CaCO}_{3}$. It can be concluded that (1) the thin layer material on the outer surface of the tubing samples is $\mathrm{CaCO}_{3}$, which was formed by surface scaling; (2) $\mathrm{Fe}_{2} \mathrm{O}_{3}$ and $\mathrm{Fe}_{3} \mathrm{O}_{4}$ were the main corrosion products.

4.2. Influencing Factors of Corrosion. The field data showed that the packer was not completely sealed after the comple- tion of the well, so the oil (gas) well protection fluid with passivation function was injected immediately. In the process of production, there was leakage of protective solution, so clean water was used to make up the solution, which contains a certain amount of dissolved oxygen. The gas composition analysis results showed that the $\mathrm{CO}_{2}$ content was $2.37 \%$. Therefore, the corrosion environment of the outer wall of the tubing was as follows:

(1) Below the liquid level: water, dissolved oxygen, dissolved $\mathrm{CO}_{2}$, etc.

(2) Above the liquid level: water vapor, oxygen, $\mathrm{CO}_{2}$, etc.

The corrosion test results under simulated conditions showed that the corrosion rate of the sample in the liquid phase was much higher than that in the gas phase, which was about 15 times. This was consistent with the situation 


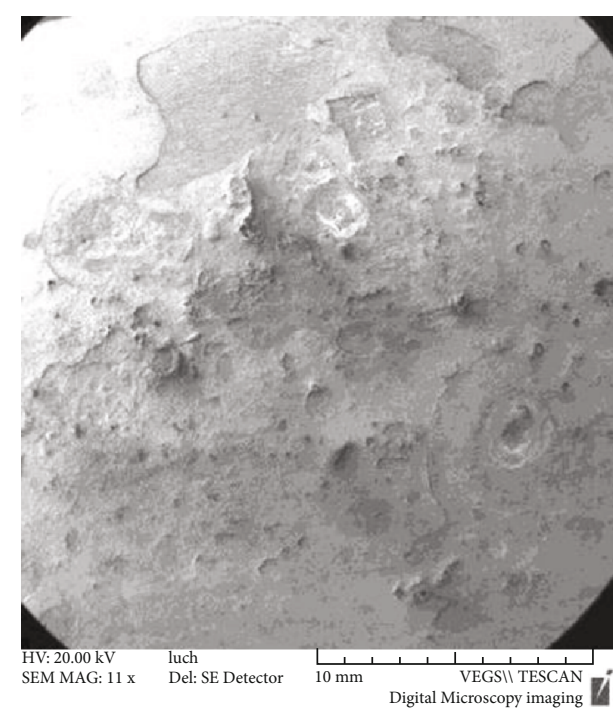

(a)

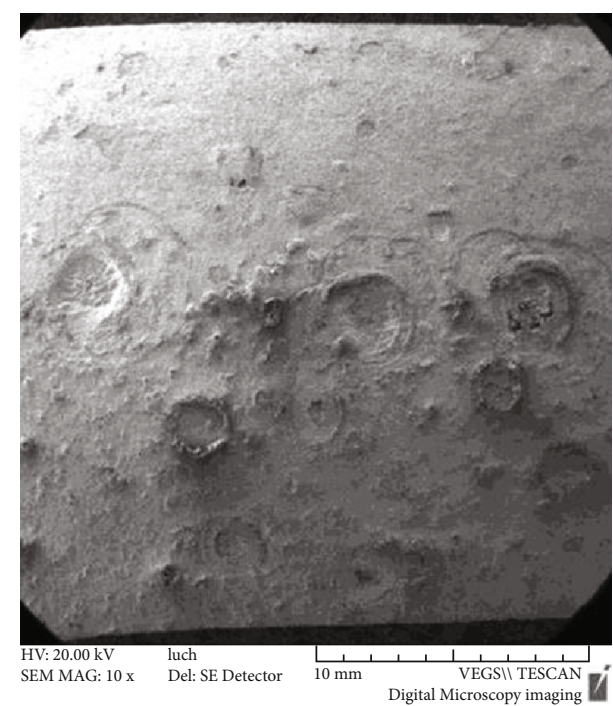

(b)

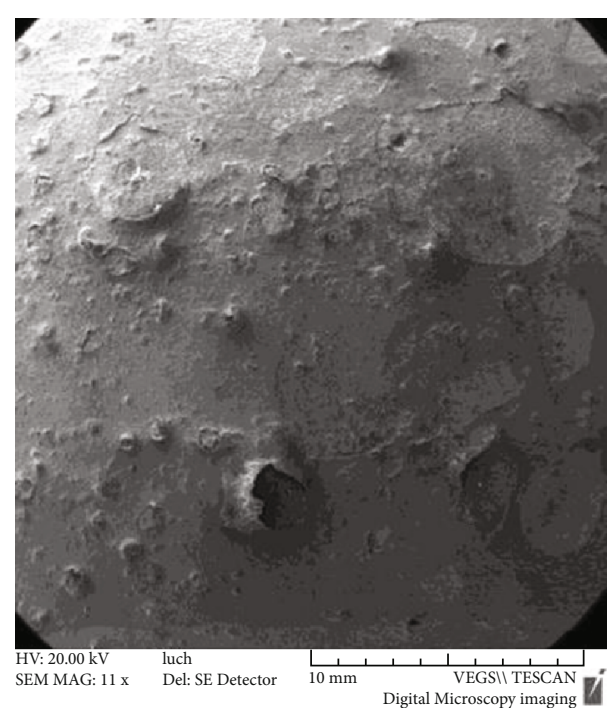

(c)

FigurE 6: Surface morphologies of samples ((a) 258\#, (b) 259\#, and (c) 364\#).

that the outer wall (containing $\mathrm{O}_{2}$ ) of the tubing was more seriously corroded than the inner wall (without $\mathrm{O}_{2}$ ) and the middle and lower part (liquid phase) of the outer wall of the tubing was more seriously corroded than the upper part (gas phase).

It could be concluded that dissolved oxygen was the main factor leading to the outer wall corrosion of tubing. The corrosion under scale in dissolved oxygen was the main reason for the formation of local corrosion pits on the outer wall of tubing.

\subsection{Corrosion Mechanism Analysis}

(1) Dissolved oxygen corrosion

Dissolved oxygen corrosion of tubing outer wall in aqueous solution is an electrochemical corrosion process, and its corrosion mechanism is as follows [14-19]:

Anode reaction: $\mathrm{Fe}=\mathrm{Fe}^{2+}+2 e$
Cathode reaction: $\mathrm{O}_{2}+2 \mathrm{H}_{2} \mathrm{O}+4 e=4 \mathrm{OH}^{-}$

In solution: $\mathrm{Fe}^{2+}+2 \mathrm{OH}^{-}=\mathrm{Fe}(\mathrm{OH})_{2}$

$\mathrm{Fe}(\mathrm{OH})_{2}$ can be further oxidized: $4 \mathrm{Fe}(\mathrm{OH})_{2}+\mathrm{O}_{2}+2 \mathrm{H}_{2}$ $\mathrm{O}=4 \mathrm{Fe}(\mathrm{OH})_{3}$

In the case of little oxygen, $\mathrm{Fe}(\mathrm{OH})_{2}$ and $\mathrm{Fe}(\mathrm{OH})_{3}$ can also react as follows:

$2 \mathrm{Fe}(\mathrm{OH})_{3}+\mathrm{Fe}(\mathrm{OH})_{2}=\mathrm{Fe}_{3} \mathrm{O}_{4}+4 \mathrm{H}_{2} \mathrm{O}$

In a dry environment, $\mathrm{Fe}(\mathrm{OH})_{3}$ dehydrates: $2 \mathrm{Fe}(\mathrm{OH})_{3}$ $=\mathrm{Fe}_{2} \mathrm{O}_{3}+3 \mathrm{H}_{2} \mathrm{O}$

(2) Subscale corrosion

The local corrosion of the tubing wall caused by dissolved oxygen is related to the deposition of corrosion product film and $\mathrm{CaCO}_{3}$ deposit. Due to the influence of scale layer and corrosion product film, the flow of the medium on the surface and the diffusion of the dielectric are limited, resulting in large changes in the composition and $\mathrm{pH}$ value of the 

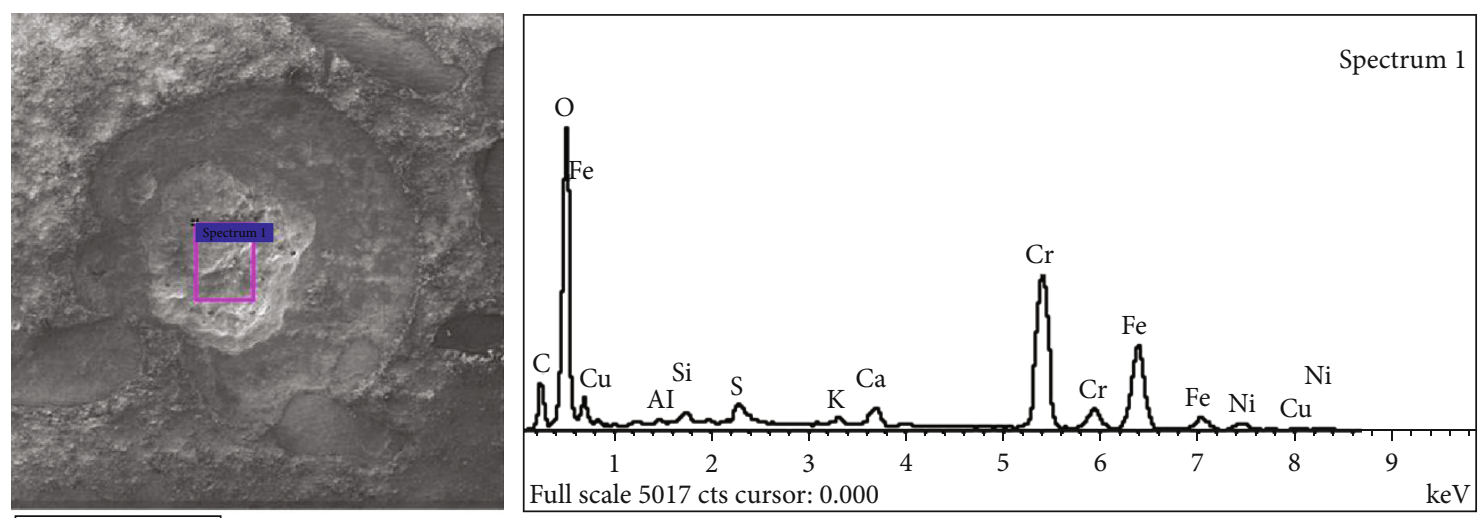

$3 \mathrm{~mm} \quad$ Electron image 1
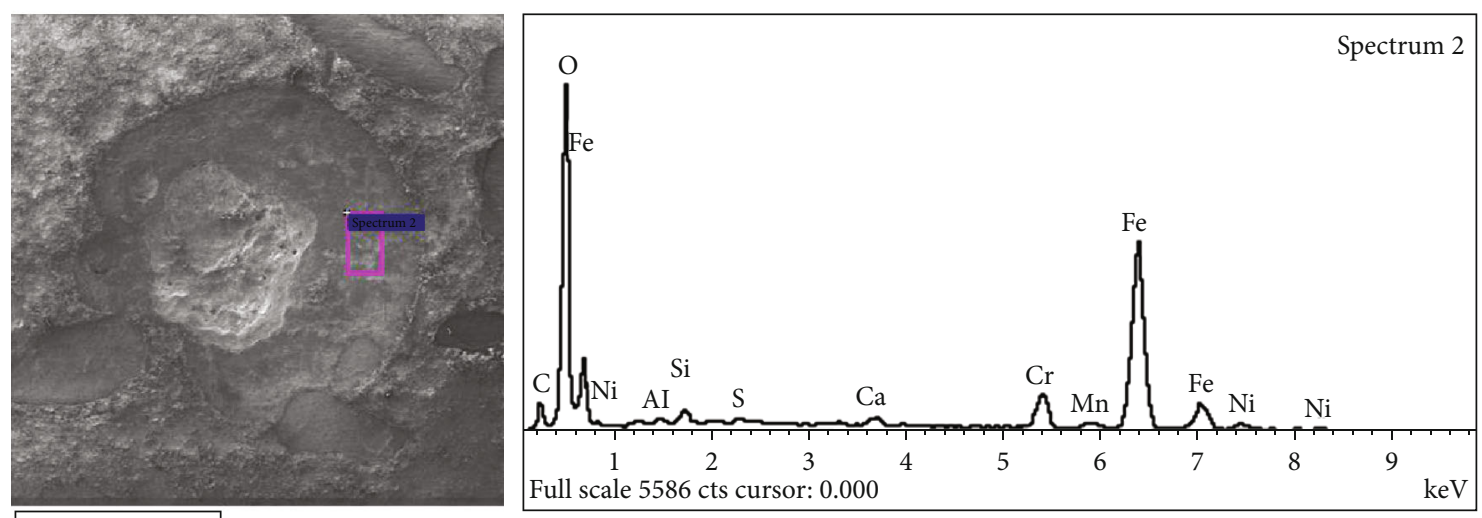

$3 \mathrm{~mm}$

Electron image 1
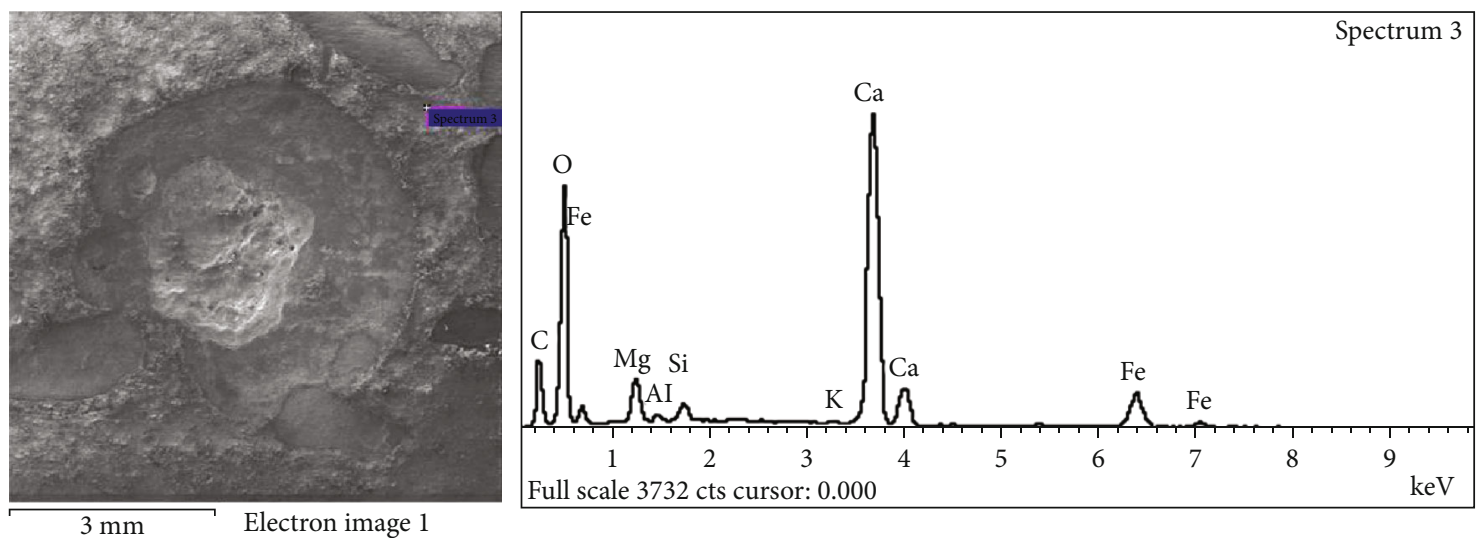

FIGURE 7: Morphology of corrosion pit and EDS analysis of corrosion products inside and outside pit of 258\# sample. 

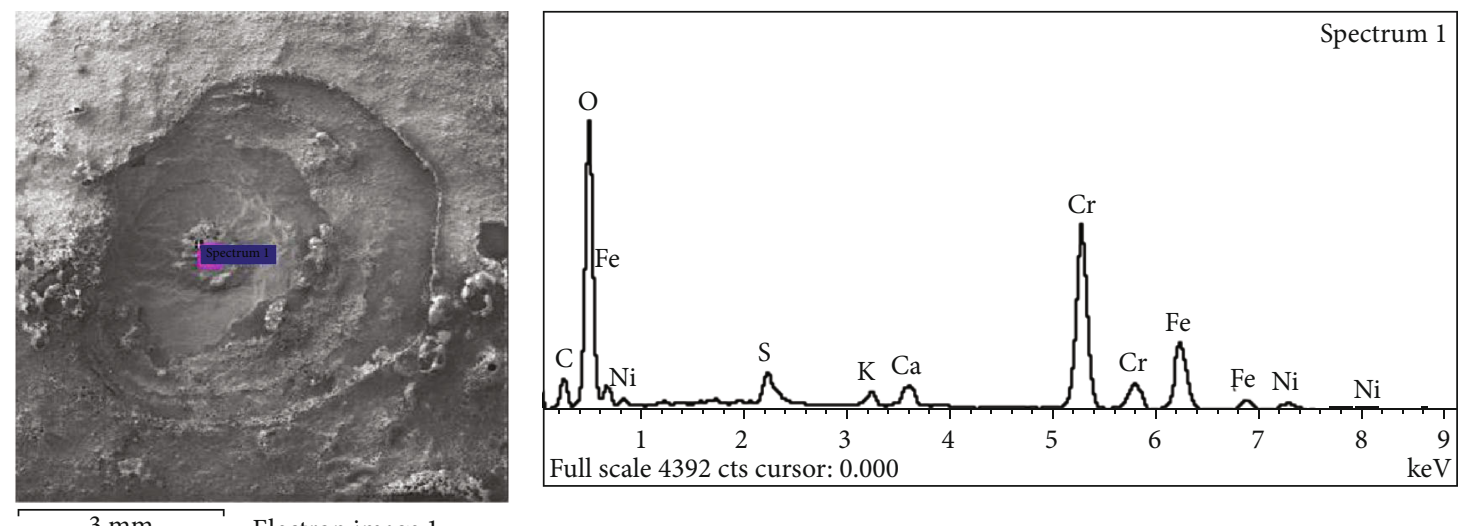

$3 \mathrm{~mm}$ Electron image 1
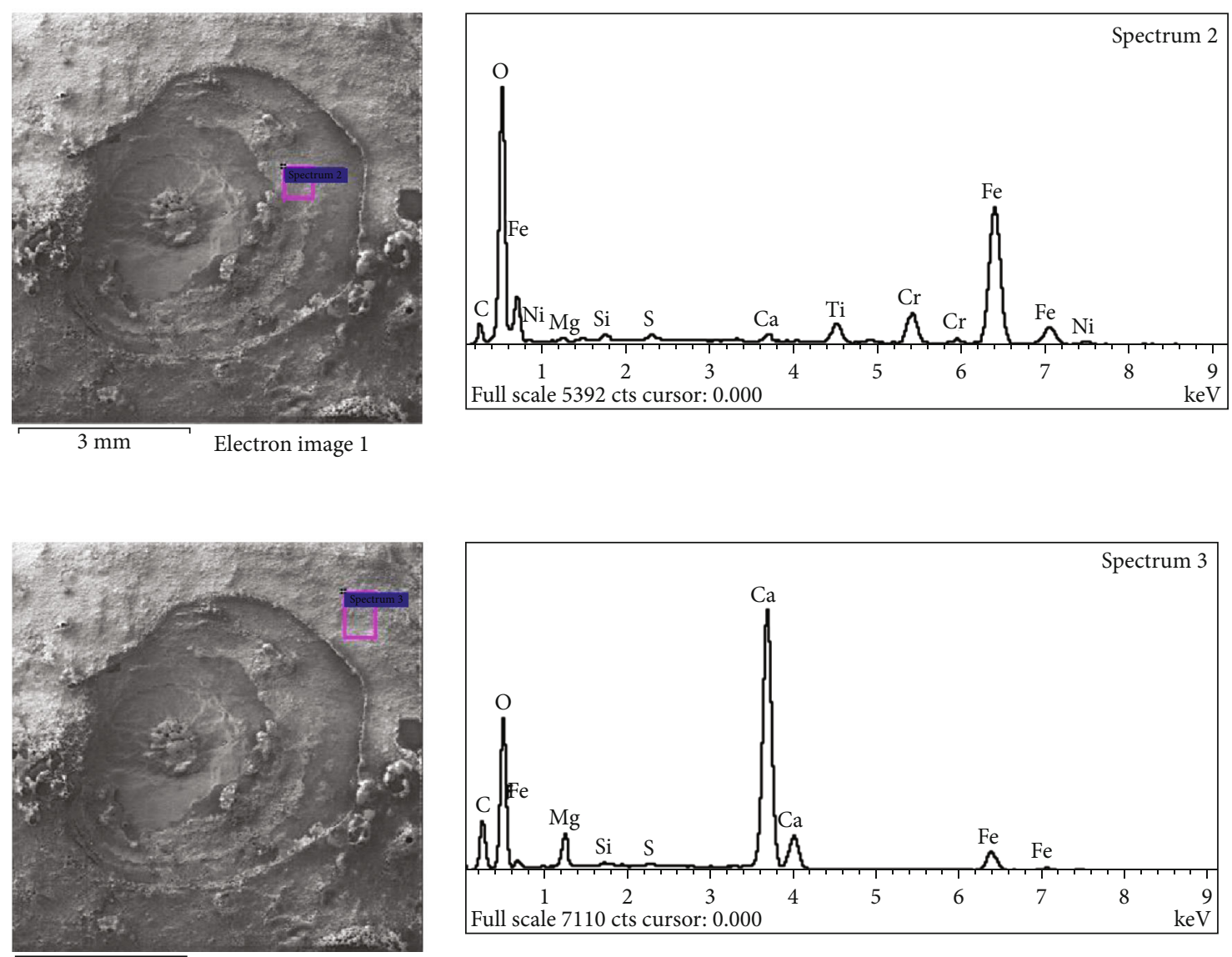

$3 \mathrm{~mm}$

Electron image 1

FIGURE 8: Morphology of corrosion pit and EDS analysis of corrosion products inside and outside pit of 259\# sample. 

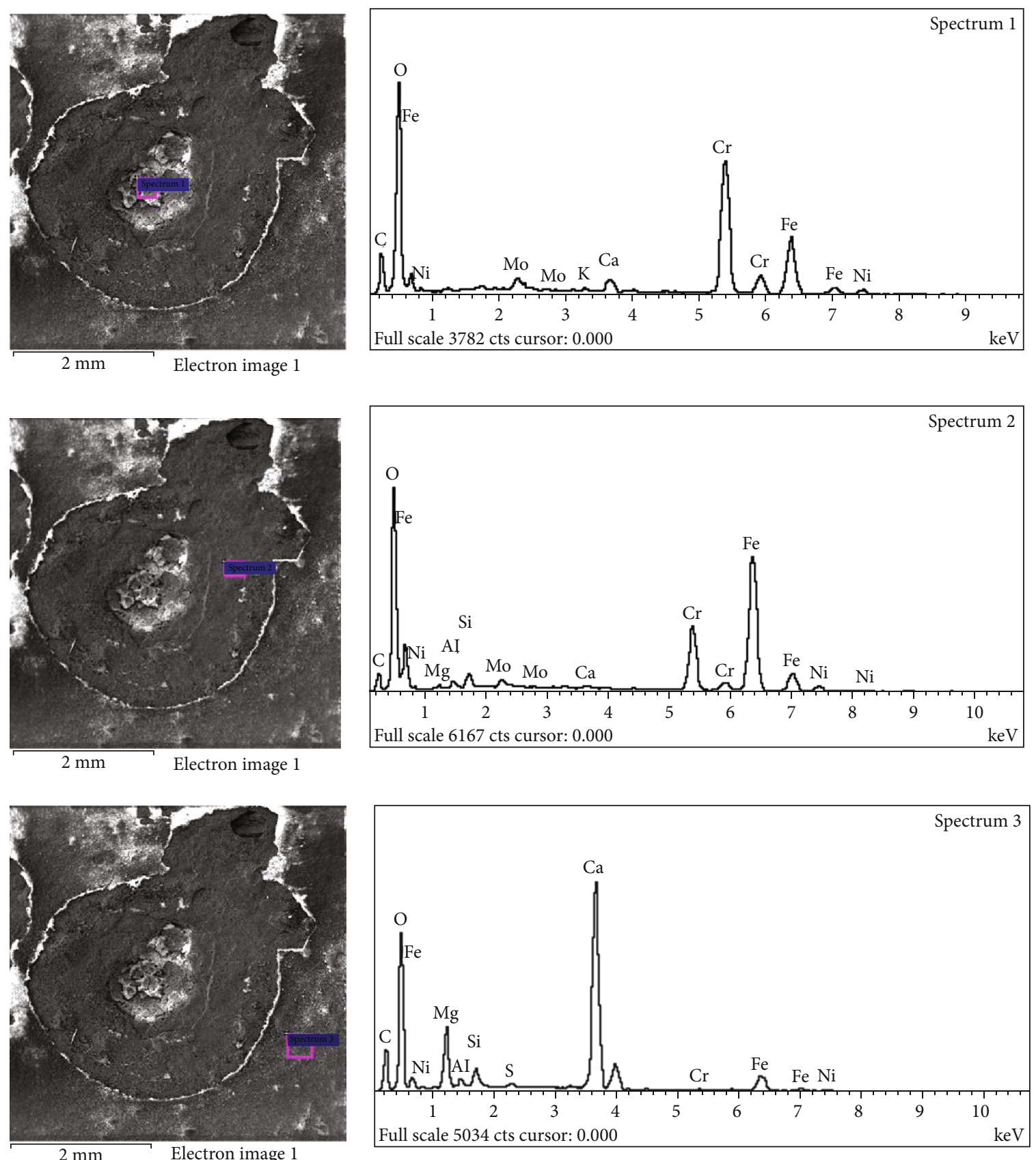

FIGURE 9: Morphology of corrosion pit and EDS analysis of corrosion products inside and outside pit of 364\# sample.

TABLE 7: Composition analysis results of corrosion products at different positions of 258\# sample surface.

\begin{tabular}{|c|c|c|c|c|c|c|c|c|c|c|c|c|c|c|c|}
\hline \multicolumn{2}{|c|}{ Number } & \multirow{2}{*}{$\begin{array}{c}\mathrm{C} \\
13.48\end{array}$} & \multirow{2}{*}{$\begin{array}{c}\mathrm{O} \\
35.04\end{array}$} & \multirow[t]{2}{*}{$\mathrm{Mg}$} & \multirow{2}{*}{$\begin{array}{c}\mathrm{Al} \\
0.28\end{array}$} & \multirow{2}{*}{$\begin{array}{c}\mathrm{Si} \\
0.51\end{array}$} & \multirow{2}{*}{$\frac{\mathrm{K}}{0.52}$} & \multirow{2}{*}{$\begin{array}{c}S \\
0.90\end{array}$} & \multirow{2}{*}{$\begin{array}{c}\mathrm{Ca} \\
1.35\end{array}$} & \multirow{2}{*}{$\begin{array}{c}\mathrm{Cr} \\
24.41\end{array}$} & \multirow[t]{2}{*}{$\mathrm{Mn}$} & \multirow{2}{*}{$\begin{array}{c}\mathrm{Fe} \\
20.46\end{array}$} & \multirow{2}{*}{$\frac{\mathrm{Ni}}{2.35}$} & \multirow{2}{*}{$\begin{array}{c}\mathrm{Cu} \\
0.70\end{array}$} & \multirow{2}{*}{$\begin{array}{r}\text { Total } \\
100.00\end{array}$} \\
\hline & Weight\% & & & & & & & & & & & & & & \\
\hline 1 & Atomic\% & 26.08 & 50.90 & & 0.24 & 0.42 & 0.31 & 0.66 & 0.78 & 10.91 & & 8.51 & 0.93 & 0.26 & \\
\hline \multirow{2}{*}{2} & Weight $\%$ & 8.17 & 37.58 & & 0.40 & 0.73 & & 0.34 & 0.72 & 4.76 & 0.48 & 44.92 & 1.91 & & 100.00 \\
\hline & Atomic\% & 16.86 & 58.20 & & 0.36 & 0.64 & & 0.26 & 0.45 & 2.27 & 0.21 & 19.93 & 0.81 & & \\
\hline \multirow{2}{*}{3} & Weight\% & 12.39 & 53.57 & 2.47 & 0.32 & 0.73 & 0.21 & & 22.90 & & & 7.41 & & & 100.00 \\
\hline & Atomic\% & 19.72 & 64.04 & 1.94 & 0.23 & 0.50 & 0.10 & & 10.93 & & & 2.54 & & & \\
\hline
\end{tabular}


TABLE 8: Composition analysis results of corrosion products at different positions of 259\# sample surface.

\begin{tabular}{|c|c|c|c|c|c|c|c|c|c|c|c|c|c|c|}
\hline \multicolumn{2}{|c|}{ Number } & \multirow{2}{*}{$\begin{array}{c}\mathrm{C} \\
9.88\end{array}$} & \multirow{2}{*}{$\frac{\mathrm{O}}{34.54}$} & \multirow[t]{2}{*}{$\mathrm{Mg}$} & \multirow[t]{2}{*}{$\mathrm{Al}$} & \multirow[t]{2}{*}{$\mathrm{Si}$} & \multirow{2}{*}{$\begin{array}{c}\mathrm{K} \\
1.08\end{array}$} & \multirow{2}{*}{$\frac{S}{1.48}$} & \multirow{2}{*}{$\begin{array}{c}\mathrm{Ca} \\
1.78\end{array}$} & \multirow{2}{*}{$\frac{\mathrm{Cr}}{31.70}$} & \multirow[t]{2}{*}{$\mathrm{Ti}$} & \multirow{2}{*}{$\frac{\mathrm{Fe}}{17.07}$} & \multirow{2}{*}{$\begin{array}{c}\mathrm{Ni} \\
2.46\end{array}$} & \multirow{2}{*}{$\frac{\text { Total }}{100.00}$} \\
\hline 1 & Weight\% & & & & & & & & & & & & & \\
\hline 1 & Atomic\% & 20.28 & 53.21 & & & & 0.68 & 1.14 & 1.09 & 15.03 & & 7.54 & 1.03 & \\
\hline \multirow{2}{*}{2} & Weight $\%$ & 7.76 & 39.15 & 0.43 & 0.39 & & & 0.41 & 0.72 & 5.61 & 2.75 & 41.30 & 1.48 & 100.00 \\
\hline & Atomic\% & 15.82 & 59.89 & 0.43 & 0.34 & & & 0.31 & 0.44 & 2.64 & 1.40 & 18.10 & 0.62 & \\
\hline \multirow{2}{*}{3} & Weight $\%$ & 11.99 & 52.56 & 2.60 & & 0.17 & & 0.20 & 26.82 & & & 5.65 & & 100.00 \\
\hline & Atomic\% & 19.30 & 63.50 & 2.07 & & 0.12 & & 0.12 & 12.93 & & & 1.96 & & \\
\hline
\end{tabular}

TABLE 9: Composition analysis results of corrosion products at different positions of 364\# sample surface.

\begin{tabular}{rcccccccccccccc}
\hline \multicolumn{2}{c}{ Number } & $\mathrm{C}$ & $\mathrm{O}$ & $\mathrm{Mg}$ & $\mathrm{Al}$ & $\mathrm{Si}$ & $\mathrm{K}$ & $\mathrm{S}$ & $\mathrm{Ca}$ & $\mathrm{Cr}$ & $\mathrm{Fe}$ & $\mathrm{Ni}$ & $\mathrm{Mo}$ & $\mathrm{Total}$ \\
\hline \multirow{2}{*}{1} & Weight\% & 14.46 & 33.68 & & & & 0.30 & & 1.35 & 28.43 & 17.77 & 2.12 & 1.88 & 100.00 \\
& Atomic\% & 28.19 & 49.28 & & & & 0.18 & & 0.79 & 12.80 & 7.45 & 0.85 & 0.46 & \\
\multirow{2}{*}{2} & Weight\% & 8.45 & 30.52 & 0.37 & 0.55 & 1.07 & & & 0.28 & 12.46 & 42.50 & 2.24 & 1.56 & 100.00 \\
& Atomic\% & 18.77 & 50.91 & 0.40 & 0.54 & 1.02 & & & 0.18 & 6.40 & 20.31 & 1.02 & 0.44 & \\
& Weight\% & 12.32 & 52.00 & 5.09 & 0.53 & 1.26 & & 0.22 & 22.86 & 0.28 & 4.97 & 0.46 & 100.00 \\
& Atomic\% & 19.62 & 62.15 & 4.01 & 0.37 & 0.86 & & 0.13 & 10.91 & 0.10 & 1.70 & 0.15 & \\
\hline
\end{tabular}

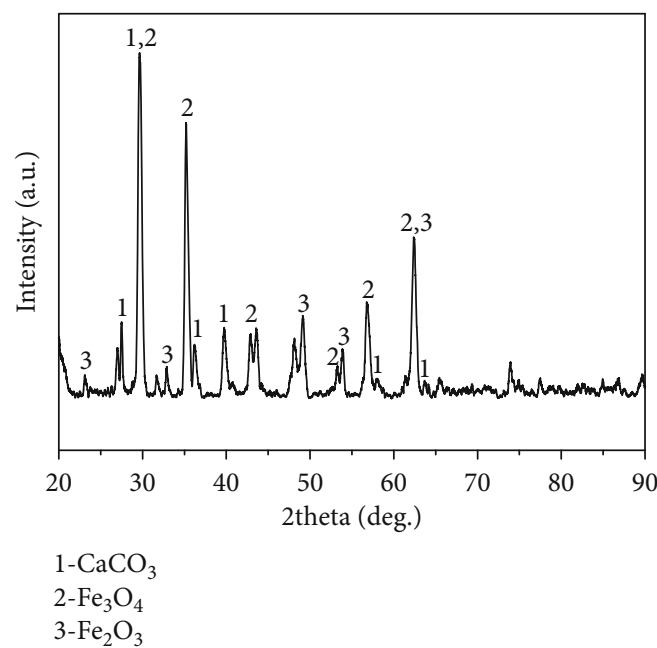

(a)

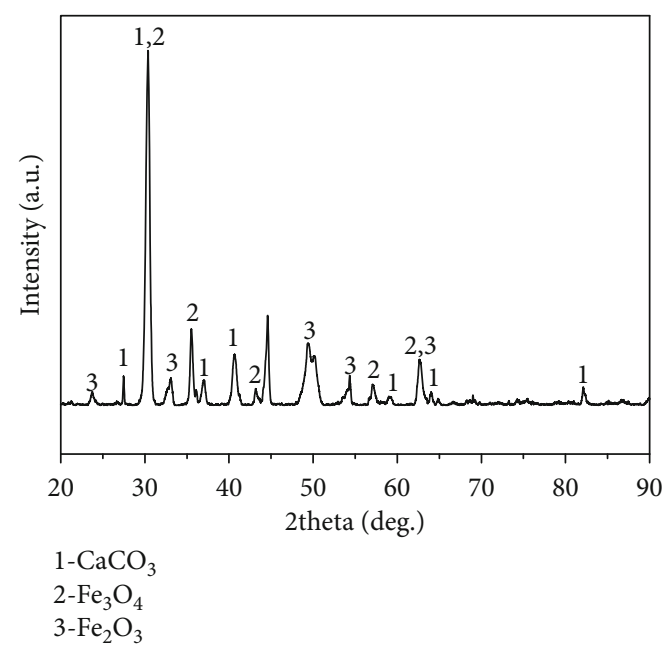

(b)

Figure 10: Surface X-ray diffraction analysis results of the sample ((a) blocky; (b) powder).

medium in the blocked corrosion pit, resulting in the blocking battery corrosion [20,21].

In addition, when an incomplete or partially damaged or detached film layer is formed on the outer surface of the tubing, corrosive electrocution or blocking batteries with a strong autocatalytic effect are formed between different surface coverage areas, which will also accelerate local corrosion.

\section{Conclusions and Recommendations}

\subsection{The Conclusion}

(1) The impact property, tensile strength, yield strength, and elongation of the four tubing meet the requirements of API Spec 5CT for P110 tubing; the metallographic structure is normal. All of them are tempered martensite, the grain size is grade 9.0, and there is no oversize nonmetallic inclusion; there is no difference in chemical composition and corrosion resistance

(2) Dissolved oxygen will lead to a significant increase in the corrosion rate of the sample. Compared with the conditions without dissolved oxygen, the corrosion rate of the sample in the gas phase increases by 2 to 3 times, and the corrosion rate in the liquid phase increases by 70 to 80 times

(3) Subscale corrosion under the condition of dissolved oxygen is the main reason for the formation of local corrosion pits on the outer wall of the tubing 
5.2. Suggestion. When taking clear water to replenish fluids, avoid direct use. Local corrosion of the tubing surface can be controlled by adding a deoxidizer, a corrosion inhibitor, or a combination of both.

\section{Data Availability}

The data used to support the findings of this study are available from the corresponding author upon request.

\section{Conflicts of Interest}

The authors declare that they have no conflicts of interest.

\section{References}

[1] Z. Y. Liu, X. Z. Wang, R. K. Liu, C. W. Du, and X. G. Li, “Electrochemical and sulfide stress corrosion cracking behaviors of tubing steels in a $\mathrm{H}_{2} \mathrm{~S} / \mathrm{CO}_{2}$ annular Environment," Journal of Materials Engineering and Performance, vol. 23, no. 4, pp. 1279-1287, 2014.

[2] X. W. Lei, Y. R. Feng, A. Q. Fu et al., "Investigation of stress corrosion cracking behavior of super $13 \mathrm{Cr}$ tubing by fullscale tubular goods corrosion test system," Engineering Failure Analysis, vol. 50, pp. 62-70, 2015.

[3] S. Nešić, "Key issues related to modelling of internal corrosion of oil and gas pipelines - a review," Corrosion Science, vol. 49, no. 12, pp. 4308-4338, 2007.

[4] S. D. Zhu, J. F. Wei, R. Cai, Z. Q. Bai, and G. S. Zhou, "Corrosion failure analysis of high strength grade super $13 \mathrm{Cr}-110$ tubing string," Engineering Failure Analysis, vol. 18, no. 8, pp. 2222-2231, 2011.

[5] H. Mansoori, R. Mirzaee, F. Esmaeilzadeh, A. Vojood, and A. S. Dowrani, "Pitting corrosion failure analysis of a wet gas pipeline," Engineering Failure Analysis, vol. 82, pp. 16-25, 2017.

[6] P. Li, Y. Zhao, B. Liu et al., "Experimental testing and numerical simulation to analyze the corrosion failures of single well pipelines in Tahe oilfield," Engineering Failure Analysis, vol. 80, pp. 112-122, 2017.

[7] H. Wang and I. J. Duncan, "Likelihood, causes, and consequences of focused leakage and rupture of U.S. natural gas transmission pipelines," Journal of Loss Prevention in the Process Industries, vol. 30, pp. 177-187, 2014.

[8] A. V. Afanasyev, A. A. Mel'nikov, S. V. Konovalov, and M. I. Vaskov, "The analysis of the influence of various factors on the development of stress corrosion defects in the main gas pipeline walls in the conditions of the European part of the Russian Federation," International Journal of Corrosion, vol. 2018, 10 pages, 2018.

[9] D. B. Darmadi, N. A. Sugiarto, and F. Gapsari, "Stress corrosion cracking at ASTM A36 plate with varied grain orientation," International Review of Mechanical Engineering (IREME), vol. 12, no. 12, pp. 987-991, 2018.

[10] M. Chausov, P. Maruschak, A. Pylypenko, and A. Sorochak, "Effect of impact-oscillatory loading on the variation of mechanical properties and crack resistance of pipe steel," in Degradation Assessment and Failure Prevention of Pipeline Systems Lecture Notes in Civil Engineering, vol. 102, Springer, Cham, 2021.
[11] D. K. Jana, B. Bej, M. H. A. Wahab, and A. Mukherjee, "Novel type-2 fuzzy logic approach for inference of corrosion failure likelihood of oil and gas pipeline industry," Engineering Failure Analysis, vol. 80, pp. 299-311, 2017.

[12] O. Shabarchin and S. Tesfamariam, "Internal corrosion hazard assessment of oil \& gas pipelines using Bayesian belief network model," Journal of Loss Prevention in the Process Industries, vol. 40, pp. 479-495, 2016.

[13] Y. Zhang and W. G. Weng, "Bayesian network model for buried gas pipeline failure analysis caused by corrosion and external interference," Reliability Engineering and System Safety, vol. 203, p. 107089, 2020.

[14] G. Mcintire, J. Lippert, and J. Yudelson, "The effect of dissolved CO2and O2on the corrosion of iron," Corrosion, vol. 46, no. 2, pp. 91-95, 1990.

[15] V. D. Makarenko, S. P. Shatilo, K. K. Gumerskii, and V. A. Belyaev, "Effect of oxygen and hydrogen sulfide on carbon dioxide corrosion of welded structures of oil and gas installations," Chemical and Petroleum Engineering, vol. 36, no. 2, pp. 125-130, 2000.

[16] N. R. Rosli, Y. S. Choi, and D. Young, Impact of oxygen ingress in $\mathrm{CO}_{2}$ corrosion of mild steel, 2014, NACE-4299.

[17] Y. Li, J. Wu, D. Zhang, Y. Wang, and B. Hou, "The electrochemical reduction reaction of dissolved oxygen on Q235 carbon steel in alkaline solution containing chloride ions," Journal of Solid State Electrochemistry, vol. 14, no. 9, pp. 1667-1673, 2010.

[18] X. Lin, W. Liu, F. Wu, C. Xu, J. Dou, and M. Lu, "Effect of $\mathrm{O}_{2}$ on corrosion of $3 \mathrm{Cr}$ steel in high temperature and high pressure $\mathrm{CO}_{2}-\mathrm{O}_{2}$ environment," Applied Surface Science, vol. 329, pp. 104-115, 2015.

[19] P. Sarin, V. L. Snoeyink, J. Bebee et al., "Iron release from corroded iron pipes in drinking water distribution systems: effect of dissolved oxygen," Water Research, vol. 38, no. 5, pp. 12591269, 2004.

[20] N. M. Alanazi, A. M. El-Sherik, A. H. Rasheed, S. H. Amar, M. R. Dossary, and M. N. Alneemai, "Corrosion of pipeline steel X60 under field-collected sludge deposit in a simulated sour environment," Corrosion, vol. 71, no. 3, pp. 305-315, 2015.

[21] G. A. Zhang, N. Yu, L. Y. Yang, and X. P. Guo, "Galvanic corrosion behavior of deposit-covered and uncovered carbon steel," Corrosion Science, vol. 86, pp. 202-212, 2014. 